\title{
Freshwater Fungal Richness, Their Assessment and Impact on Human Welfare: A Review
}

\author{
Haninder Maini ${ }^{1}$, Arjun Shukla ${ }^{2}$ \\ ${ }^{1}$ Department of Zoology, Govt. M.H. College of Home Science and Science for Women, Jabalpur (M.P.) \\ ${ }^{2}$ Department of Zoology, Govt. Model Science (Autonomous) College, Jabalpur (M.P.)
}

\begin{abstract}
Fungi are eukaryotic, heterotrophic organism, including both single-celled yeasts and multi-cellular filamentous fungi which can survive in oligotrophic environments, also called recyclers of organic material. The diversity spectrum and identification method of fungi are reviewed in such order that is adapted to aquatic ecosystem as well as their contribution to the environment and significant to human welfare.
\end{abstract}

Keywords: Aquatic Fungi, Isolation Method, Hazards

\section{Introduction}

The variety and galaxy of fungi and their natural beauty occupy prime place in the biological world and India has been the cradle for such fungi. There are approximately 1.5 million fungal species on earth that estimated by [1]. Of these, only around 3000 species are known to be associated with aquatic habitats and only 465 species occur in marine waters [2]. About 10,000 fungal genera are reported around the world out of which one fifth of the world's mycodiversity i.e., more than 2,000 genera and 14,000 species which is largest biotic community after insect known from India at the globe level and [3] recorded 185 more new genera of fungi and complied with the account of Indian Fungi. A broad definition of 'freshwater fungi' includes any species which, for the whole or part of their life cycle, rely on free freshwater A large number of "extra aquatic" fungi had been reported on insect as well as materials like nails, hairs etc. Fungi are omnipresent and therefore associated with almost every organism, often as parasites, sometimes as symbionts and of course as decomposers. Some predaceous and coprophilous had also been reported by [4].

\section{Diversity Stretch}

Water associated fungi have been known historically as "Phycomycetes", a functionally defined group consisting of "true fungi" colloquially known as "water moulds", which comprise of approximately 200 species inhabiting freshwater, mud and soil, many of which are parasitic [5-6].

The fungal groups that occur most commonly on submerged natural substrates are chytridiomycetes, meiosporic and mitosporic ascomycetes and basidiomycetes, and the nonfungal saprolegniales of the oomycetes [7].

Father of aquatic hyphomycetes is known to be C.T. Ingold who named them as 'Aquatic Hyphomycetes' [8]. Later it described them as "Freshwater Hyphomycetes" [9-10] which are mostly found in the temperate region. Ascomycete's fungi are found in freshwater habitats and complete a part or the whole of their life cycle within freshwater habitats [11]. Taxonomically, most aero-aquatic fungi are classified as
Ascomycota, although four aero-aquatic species have been classified as Basidiomycota, and one as Oomycete [2].

The number of species in various taxonomic groups commonly found in aquatic habitats according to [12]:

\begin{tabular}{|c|c|}
\hline \multicolumn{2}{|c|}{ Fungi From Aquatic Habitats } \\
\hline Taxonomic group & $\begin{array}{c}\text { Number of } \\
\text { species }\end{array}$ \\
\hline Chytridiomycota & 576 \\
\hline Freshwater meiosporic ascomycetes & 450 \\
\hline Mangrove meiosporic ascomycetes & 612 \\
\hline Marine meiosporic and mitosporic ascomycetes & 465 \\
\hline Ingoldian mitosporic fungi & 290 \\
\hline Aeroaquatic mitosporic fungi & 90 \\
\hline Miscellaneous mitosporic fungi 405 & 405 \\
\hline Saprolegniales & 138 \\
\hline Basidiomycetes from freshwater habitats & 11 \\
\hline Basdiomycetes from brackish and marine habitats & 10 \\
\hline Total number of taxa & 3047 \\
\hline
\end{tabular}

\section{Fungi Analysis Methods}

A number of different methods should be used to analyse water moulds suggest as in [13] including culture, measurement of ergosterol, quantitative PCR, gene markers and probes, protein probes, direct observation and mass spectrometry. There is currently no international standard specifically for the measurement of fungi in drinking water, and there is no widespread adoption of other relevant standards. Furthermore, the most commonly used unit of quantification is numbers of Colony Forming Units (CFUs). However, this measure does not necessarily give an accurate representation of the number of fungi present in a sample, as not all species can be detected using culturing methods. It is also likely that one colony is formed of many different fungal structures, such as hyphae, conidia, conidiophores, from different "individuals" clumped together into one CFU. Many of the fungi that have been found in treated drinking water are known to be pathogenic, particularly Aspergillus and Candida [13]. [14-15] suggested some classical method for investigating fungal diversity such as sample collection, incubation in moist chamber, examination of fungal fruiting bodies and the employment of various ecological statistics that often used to document fungi in a specific region or on a 


\section{International Journal of Science and Research (IJSR) \\ ISSN (Online): 2319-7064 \\ Index Copernicus Value (2013): 6.14 | Impact Factor (2015): 6.391}

specific host together with correlations between fungal communities and environmental parameters [16]. This methodology however, largely relies on the discovery of fungal fruiting bodies that was dependent on the degree of fungal sporulation. The structures of fungi communities had been affected by the substrate incubation that was revealed by [17]. By using traditional methodology, it is difficult to recognise and record those fungi which cannot produce reproductive structures but exist in their hyphal states. In addition, traditional methods are often time consuming and usually acquire high taxonomic expertise, which is often not available.

As these DNA-based methods have been successful in identifying vegetative structures, they make it possible for mycologists and ecologists to obtain an understanding of fungal communities which have previously been undetected [18-19].

Now a day's, techniques such as DGGE, RFLP, T-RFLP have been developed. A DGGE profile was first reported by [20], in which DGGE was employed to detect the organisms in bacterial mats and bio films which based on the fact that PCR products can be separated electrophoretically to obtain whole-community genetic profiles and putative lineage assignments. DGGE has since been used to survey fungal pathogens in plant roots [21] and fungi previously undetected by traditional surveys were recovered. There are some other techniques such as competitive PCR and quantitative PCR, in which PCR is used to quantify the concentration of DNA to estimate the biomass of a target lineage [22].

\section{Significance of Aquatic Fungi}

The aquatic fungi play a key role in the decomposition of leaf litter in aquatic environments [23-24]. Generally, low to moderate nutrient concentrations stimulate fungal activity [25]. Aquatic fungi, being heterotrophs, are reliant upon photo synthetically produced organic matter. In order of decreasing biodegradability, the fungal community consumes microscopic algae, macroscopic aquatic macrophytes and terrestrial plant litter (including wood).In aquatic environment the planktonic taxa is an integral part of food chain which plays a significant role in freshwater food webs as organic matter decomposers and contributors to nutrient cycling, as symbionts with plants. Aquatic fungi are important for industrial and pharmaceutical use.

Some fungi, including Penicillium spp., Aspergillus spp., Fusariam spp. and Claviceps spp. are known to produce mycotoxins such as patulin, aflatoxins and zearalenone. It is thought that concentrations of mycotoxins in drinking water are low due to being diluted but it may cause serious disorders or infection to the an organism who used to port it. Fungi also produce secondary metabolites, some of which are toxins. Some of the fungal species and their produced metabolites are known to be human pathogens or allergens. Aquatic fungi are heterotrophs, i.e. they sense strictor depend on external organic matter, which may be dead or alive. Aquatic systems harbour a wealth of organisms that can serve as suitable hosts: algae from different phyla, cyanobacteria, Protistas, zooplankton, fish, birds, mussels, nematodes, crayfish, mites, insects, amphibians, mammals, plants and other fungi [26].

\section{Some aquatic fungi that found in surface water are mentioned below}

Taste of water after fungal infection and reported some species of Acremonium, Alternaria, Aspergillus, Cladosporium, Geotrichum, Paecilomyces, Penicillium, Phoma and Trichoderma, all these produces compounds that causes off tastes of water [27]. Some species of Aspergillus were reported allergens [28] while some mycotoxicant [29]. Many species of Acremonium proverd as opportunistic pathogens [30]. Alternaria speciescan cause upper respiratory tract infections and asthma [31] and some species were unusual pathogens [32]. Beauveria proved pathogenic by [33] and some Candida species described pathogenic by [34]. Byssochalmys species were called to be nonpathogenic for human welfare either it can produce myotoxin named patiulin [35].

Betina, [36] revealed that some of Ascochyta, Fusarium, Monuscus and also Anthrinium species [37], can produce myotoxin such as Fusarium produces fumonisins and trichothecenes. Lorone, [38] studied on pathogenic effect of aquatic fungi and resulted that Scopulariopsis and Exophilia (yeast like) are pathogenic whereas Scopulariopsis causes nail infections and occasionally subcutaneous and invasive infection, some Epicoccum speciesarenon-pathogenic while some Aspergillus species causes invasive aspergillosis and some Fusarium species were reported opportunistic pathogen that can also causes eye infections and disseminated systemic infections. Phoma have some species that were proved to cause opportunistic phaeohypthomycosis, allergies and respiratory infections. Some Penicillium species also implicated in a range of diseases causing germ but its significant causes were unknown Stachybotrys chartarum also produces mycotoxins, and they were proved potentially pathogenic to human welfare.

Lecythophora species were reported are pathogen [39] and Geotrichum species revealed pathogenic [40,27]. Some species of Paecilomyces were also well known pathogen [41]. In case of Cladosporium that were reported as one of known causative of skin, toenail, sinusitis and pulmonary infections [42]. Species of Verticillium were also reported as a possible cause of keratitis [43].

\section{Conclusion}

Fungi are not only beautiful but play a significant role in the daily life of human beings besides their utilization in industry, agriculture, medicine, food industry, textiles, bioremediation, natural cycling, as bio fertilizers and many other ways. The review reveals on diversity for which population approaches and molecular data are needed to resolve phylogenetic relationships and cryptic species to fully assess aquatic fungal diversity. There is clear evidence that fungi trigger a range of allergic responses, and signifies some fungi can pathogenic to human welfare. In other hand fungal biotechnology has become an integral part of the human welfare which is now an emerging branch of 


\section{International Journal of Science and Research (IJSR) \\ ISSN (Online): 2319-7064 \\ Index Copernicus Value (2013): 6.14 | Impact Factor (2015): 6.391}

bioscience to study further on research to find new species of aquatic fungi and their monitoring for the scientist and scholars.

\section{References}

[1] K.D. Hyde, L. Cai, R. Jeewon, “Tropical Fungi. In The Fungal Community: Its organization and role in the ecosystem," 3rd edition. CRC Press, Taylor \& Francis Books, U.S.A. pp. 93-115, 2005.

[2] C.A. Shearer, E. Descals, B. Kohlmeyer, J. Kohlmeyer, L. Marvanovsa, D. Padgett, "Fungal biodiversity in aquatic habitats," Biodiversity Conserv. 16(1):49-67, 2007.

[3] K.S. Bilgrami, S. Jamaluddin, M.A. Rizwi, "Fungi of India - List and Reference," (New Delhi: Today and tomorrow's Printers \& Publisher). pp. 798, 1991.

[4] R. Dayal, R.N. Gupta, "Studies on Predaceous FungiIV. Some members of Hyphomycetes," Proc. Nat. Acad. Sci. India. 46:237-240, 1976.

[5] B. Czeczuga, A. Godlewska, "Aquatic fungi growing on feathers of wild and domestic bird species in limnological different water bodies," Polish Journal of Environmental Studies, 13(1):21-31, 2004.

[6] J. Nechwatal, A. Wielgloss, K. Mendgen, “ Pythium phragmitis sp. nov., a new species close to $P$. arrhenomanes as a pathogen of common reed Phragmites australis," Mycological Research, 109(12):1337-1346, 2005.

[7] C.A. Shearer, E. Descals, B. Kohlmeyer, L. Marvanova, D. Padgett, H.A. Raja, P. Schmit, H.A. Thorton, H. Voglymayr, "Fungal Biodiversity in Aquatic Habitats," Biodivers Conserv. 16:49-67, 2006.

[8] C.T. Ingold, "Aquatic hyphomycetes of decaying older leaves,” Trans. Br. Mycol. Soc. 25:339-417, 1947.

[9] S. Nilsson, "Freshwater hyphomycetes: Taxanomy, Morphology and Ecology," Symb. Bot. Ups. 18:1-130, 1964.

[10] J. Wesbster, E. Descals, "The telomorphs of waterborne hyphomycetes from freshwater, In: The Whole fungus (ed. Kendrick, B.)," National museums of Canada and Kananaskis foundation, Ottawa, Canada. 2:419-451, 1979.

[11]C.A. Shearer, "Freshwater Ascomycetes," Nova Hedwigia," 56:1-33, 1993.

[12] A. Carol, D. Enrique, K. Brigitte, A. Holly, "Fungal biodiversity in aquatic habitats," Biodiversity Conserv. 16:49-67, 2007.

[13] Defra, department for environment food and rural affair, WD 0906, "A Review of Fungi in Drinking Water and the Implications for Human Health," Final Report, 2011.

[14] C.K.M. Tsui, K.D. Hyde, I.J. Hodgkiss, "Paraniesslia tuberculata gen. et sp. nov., and new records or species of Clypeosphaeria, Leptosphaeria and Astrosphaeriella in Hong Kong freshwater habitats," Mycologia. 93:1002-1009, 2001a.

[15] J. Luo, J.F. Yin, L. Cai, K.Q. Zhang, K.D. Hyde, "Freshwater fungi in Lake Dianchi, a heavily polluted lake in Yunnan," China. Fungal Diversity. 16:93-112, 2004.

[16] C.K.M. Tsui, K.D. Hyde, J. Hodgkiss, "Colonization patterns of wood-inhabiting fungi on baits in Hong
Kong rivers, with reference to the effects of organic pollution," Antonie van Leeuwenhoek. 79:33-38, 2001b.

[17] K.D. Hyde, T.K. Goh, "Fungi on submerged wood in Lake Barrine, north Queensland, Australia," Mycological Research, 102:739-749, 1998.

[18] S.M. Berch, T.R. Allen, M.L. Berbee, "Molecular detection, community structure and phylogeny of ericoid mycorrhizal fungi," Plant Soil. 244: 55-66, 2002.

[19] P. Vandenkoornhuyse, S.L. Baldauf, C. Leyval, J. Straczek, P.W. Young, "Extensive fungal diversity in plant roots," Science. 295:2051, 2002.

[20] G. Muyzer, E.C. de Waal, A.G. Uitterlinden, "Profiling of complex microbial populations by denaturing gradient gel electrophoresis analysis of polymerase chain reaction-amplified genes encoding for $16 \mathrm{~S}$ rRNA." Applied Environmental Microbiology. 59:695700, 1993.

[21]G.A. Kowalchuk, S. Gerards, J.W. Woldendorp, "Detection and characterization of fungal infections of Ammophila arenaria (Marram grass) roots by denaturing gradient gel electrophoresis of specifically amplified 18S rDNA," Applied Environmental Microbiology, 63:3858-3865, 1997.

[22] P.D. Siebert, J.W. Larrick, “Competitive PCR”. Nature 395:557-558, 1992.

[23] F. Barlocher, "The Ecology of Aquatic Hyphomycetes," Springer-Verlang, Berlin, 1992.

[24] M.O. Gessner, E. Chauvet, M.A. Dobson, "Perspective on leaf litter breakdown in streams," Oikos. 85:377-384, 1999.

[25] V. Gulis, K. Suberkropp, "Effects of whole-stream nutrient enrichment on the concentration and abundance of aquatic hyphomycete conidia in transport," Mycologia. 96(1):57-65, 2004.

[26] F.K. Sparrow, “Aquatic Phycomycetes" (Second Rev.) The University of Michigan Press, Ann Arbor, 1960.

[27] J. Kelley, R. Paterson, G. Kinsey, R. Pitchers, H. Rossmoore, "Identification, significance and control of fungi in water distribution systems," Water Technology Conference Proceedings: November, pp. 9-12, 1997.

[28] B. Banerjee, V.P. Kurup, "Molecular biology of Aspergillus allergens," Immunology and Allergy Clinics of North America. 18(3):601-618, 1998.

[29] M. Fox, G. Gray, K. Kavanagh, C. Lewis, S. Doyle, "Detection of Aspergillus fumigates mycotoxins: immunogen synthesis and immunoassay development," Journal of Microbiological Methods. 56(2):221-230, 2004.

[30] J. Guarro, W. Gams, I. Pujol, J. Gene, “Acremonium species: New emerging fungal opportunists -In vito antifungal susceptibilities and review," Clinical Infectious Diseases. 25:1222-9, 1997.

[31]P.M. Salo, "Exposure to Alternaria alternata in US homes is associated with asthma symptoms," J. Allergy Clin. Immunol. 118(4):892-898, 2006.

[32] S.E.M. Vermeire, H. de Jonge, K. Lagrou, D.R.J. Kuypers, "Cutaneous phaeohyphomycosis in renal allograft recipients: report of 2 cases and review of the literature," Diagnostic Microbiology and Infectious Disease. 68 (2):177-180, 2010. 
[33] M. Henke, "Human deep tissue infection with an entomopathogenic Beauveria species," Journal of Clinical Microbiology. 40(7):1095-1137, 2002.

[34] R.A. Calderone, W.A. Fonzi, "Virulence factors of Candida albicans," Trends in Microbiology. 9(7):327335, 2001.

[35] Y. Moule, F. Hatey, "Mechanism of the in vitro inhibition of transcription by patulin, a mycotoxin from Byssoclamys nivea,” FEBS Lett. 74(1): 121-125, 1977.

[36] A. Betina, "Chromatography of mycotoxins: techniques and applications," Journal of Chromatography Library, Elsevier Science Publishers, Amsterdam, the Netherlands. pp. 54, 1993.

[37] N. Magan, O. Olsen, "Mycotoxins in food: detection and control," Wood head Publishing Limited, Cambridge, UK, 2004.

[38] D.H, Larone, "Medically important fungi: A guide to identification," 4th Edition. ASM Press, Washington D.C, 2002.

[39] D.J. Marriott, K.H. Wong, E. Aznar, J.L. Harkness, D.A. Cooper, D. Muir Scytalidium dimidiatum, Lecythophora hoffmannii, "Unusual causes of fungal infections in a patient with AIDS," J. Clin. Microbiol. 35(11):2949-2952, 1997.

[40]A. Sfakianakis, "Invasive cutaneous infection with Geotrichum candidum sequential treatment with amphotericin B, voriconazole," Medical Mycology. 45(1):81-84, 2007.

[41]T.J. Walsh, A.H. Groll, "Emerging fungal pathogens: evolving challenges to immune compromised patients for the twenty-first century," Transplant Infectious Disease. 1(4): 247-261, 1999.

[42] J. Tamiskar, J. Naidu, S.M. Singh, "Phaeohyphomycotic sebaceous cyst due to Cladosporium cladosporioides: a case report and review of literature," Journal of Medical Mycology. 16(1):55-57, 2006.

[43] D.A. Sutton, A. W. Fothergill, M. G. Rinaldi, Guide to Clinically Significant Fungi, 1st ed. Williams \& Wilkins, Baltimore, 1998. 